\title{
Maribaculum marinum gen. nov., sp. nov., isolated from deep seawater
}

Correspondence

Zongze Shao

shaozz@163.com

\author{
Qiliang Lai, Jun Yuan and Zongze Shao
}

Key Laboratory of Marine Biogenetic Resources, Third Institute of Oceanography, State Oceanic Administration, PR China

\begin{abstract}
A taxonomic study was carried out on strain $\mathrm{P} 38^{\top}$, which was isolated from an enriched polycyclic aromatic hydrocarbon-degrading consortium from a deep seawater sample collected from the Indian Ocean. Phylogenetic analyses based on 16S rRNA gene sequences showed that strain $\mathrm{P} 38^{\top}$ formed a distinct evolutionary lineage within the family Hyphomonadaceae. Strain $\mathrm{P} 38^{\top}$ was most closely related to members of the genera Hyphomonas (92.3-93.5\% 16S rRNA gene sequence similarity), Hirschia (88.8\%), Maricaulis (88.3-88.6\%), Hellea (87.5\%), Oceanicaulis (87.4\%) and Robiginitomaculum (86.7\%) of the family Hyphomonadaceae. The DNA G + C content of strain $\mathrm{P}_{3} 8^{\top}$ was $61.0 \mathrm{~mol} \%$ and the predominant cellular fatty acids were $\mathrm{C}_{16: 0}$ (20\%), $\mathrm{C}_{17: 0}(5.7 \%), \mathrm{C}_{18: 1} \omega 7 c$ (37.7\%), $\mathrm{C}_{18: 0}(6.3 \%)$ and $\mathrm{C}_{18: 1} \omega 7 c 11$-methyl $(7.1 \%)$. Strain $\mathrm{P} 38^{\top}$ was distinguishable from members of phylogenetically related genera by differences in several phenotypic properties. On the basis of the phenotypic and phylogenetic data, strain $\mathrm{P} 38^{\top}$ represents a novel species of a new genus, for which the name Maribaculum marinum gen. nov., sp. nov. is proposed. The type strain of Maribaculum marinum is $\mathrm{P} 38^{\top}$ (=CCTCC AB $208227^{\top}=$ LMG $24711^{\top}=\operatorname{MCCC} 1 \mathrm{~A}^{\top} 1086^{\top}$ ).
\end{abstract}

In an attempt to investigate polycyclic aromatic hydrocarbon-degrading bacteria in deep seawater of the Indian Ocean, many bacterial strains were isolated and characterized taxonomically (Lai et al., 2009). Comparative 16S rRNA gene sequence analysis indicated that one of these isolates, designated strain $\mathrm{P} 38^{\mathrm{T}}$, formed a deep branch within the family Hyphomonadaceae. The family Hyphomonadaceae was first proposed by Lee et al. (2005) based on phylogenetic analyses of $16 \mathrm{~S}$ rRNA gene sequences. At the time of writing, the genus contains six genera: Hyphomonas (Moore et al., 1984), Hirschia (Schlesner et al., 1990), Maricaulis (Abraham et al., 2002), Oceanicaulis (Strömpl et al., 2003), Robiginitomaculum (Lee et al., 2007) and Hellea (Alain et al., 2008). Another genus, Woodsholea (Abraham et al., 2004), should be assigned to the family Hyphomonadaceae (Alain et al., 2008). Accordingly, the aim of the present work was to determine the exact taxonomic position of strain $\mathrm{P} 38^{\mathrm{T}}$.

Deep sea water was sampled at a depth of $2914 \mathrm{~m}(200 \mathrm{~m}$ above the sea floor) at the site of IR-CTD13 $\left(24.2822^{\circ} \mathrm{S}\right.$ $69.7944^{\circ} \mathrm{E}$ ) on the south-west Indian Ridge during cruise

Abbreviation: UPGMA, unweighted pair group method with arithmetic means.

The GenBank/EMBL/DDBJ accession number for the 16S rRNA gene sequence of strain $\mathrm{P} 8^{\top}$ is EU819081.

A transmission electron micrograph of strain $\mathrm{P} 38^{\top}$ and a table detailing the API ZYM characteristics of strain $\mathrm{P}^{\top} 8^{\top}$ and related genera are available with the online version of this paper.
DY-105A of R/V Da-Yang Yi-Hao in December 2005. The sample was enriched with polycyclic aromatic hydrocarbons and strains were isolated on $216 \mathrm{~L}$ marine agar medium following the method described by Lai et al. (2009). For morphological and biochemical characterization, strain $\mathrm{P} 38^{\mathrm{T}}$ was cultivated on $216 \mathrm{~L}$ agar.

General cell morphology of strain $\mathrm{P} 38^{\mathrm{T}}$ was studied under an Olympus inverted microscope using a 1-day-old culture. For electron microscopy, exponential-phase cells were harvested, suspended and absorbed onto a Formvarcarbon-coated grid and stained with phosphotungstic acid (Supplementary Fig. S1, available in IJSEM Online). The Gram reaction and tests for catalase and oxidase activities, lipase (Tween 80), amylase and hydrolysis of aesculin were carried out according to Dong \& Cai (2001). The optimal growth temperature was determined on $216 \mathrm{~L}$ agar over the range $4-55{ }^{\circ} \mathrm{C}$. Tolerance of $\mathrm{NaCl}$ was tested by using Luria-Bertani medium (Sambrook et al., 1989) supplemented with $\mathrm{NaCl}(0,0.5,1,2,3,4,5,6,7,8,9,10,12,15$, 18 and $20 \%, w / v)$. Antibiotic susceptibility tests were performed by the disc diffusion method as described by Shieh et al. (2003) with Oxoid discs. Other biochemical tests were performed with API 20NE and API ZYM strips (bioMérieux) and GN2 MicroPlates (Biolog), according to the manufacturers' instructions with the adjustment of $\mathrm{NaCl}$ to $3.0 \%$. To detect bacteriochlorophyll $a$ and carotenoids, pigments of strain $\mathrm{P} 38^{\mathrm{T}}$ were extracted with acetone/methanol $(1: 1, \mathrm{v} / \mathrm{v})$ and absorption spectra were recorded using a scanning UV/visible spectrophotometer 
(SmartSpec Plus; Bio-Rad). Additionally, the genetic potential for anoxygenic phototrophy was determined by PCR amplification of the photosynthetic reaction centre genes (pufLM) using the pufLf and pufMr primer set (Béjà et al., 2002). The results are given in the genus and species descriptions and Table 1.

Genomic DNA was prepared according to the method of Ausubel et al. (1995) and the 16S rRNA gene was amplified by PCR with primers that have been described previously (Liu \& Shao, 2005). A nearly full-length 16S rRNA gene sequence (1415 nt) of strain $\mathrm{P} 38^{\mathrm{T}}$ was determined. Sequences of related taxa were obtained from the GenBank database. Phylogenetic analysis was performed using MEGA version 4 (Tamura et al., 2007) after multiple alignment of data using DNAMAN version 5.1 (Lynnon Biosoft). Distances were calculated according to the distance options with Kimura's two-parameter model and clustering with the neighbour-joining method of Saitou \& Nei (1987), the minimum-evolution method of Rzhetsky \& Nei $(1992,1993)$ and the unweighted pair group method with arithmetic means (UPGMA) method was determined by using bootstrap values based on 1000 replications. The neighbour-joining tree is shown in Fig. 1. The results obtained with the minimum-evolution and UPGMA methods were similar to those obtained with the neighbour-joining method (not shown).

Phylogenetic analyses showed that strain $\mathrm{P} 38^{\mathrm{T}}$ formed a distinct evolutionary lineage within the family Hyphomonadaceae (Fig. 1). Strain $\mathrm{P} 38^{\mathrm{T}}$ showed the highest $16 \mathrm{~S}$ rRNA gene sequence similarity $(>97 \%)$ to sequences from strains that have not yet been assigned to any species. Of the sequences from recognized species, strain $\mathrm{P} 38^{\mathrm{T}}$ was most closely related to those from the genera Hyphomonas (92.3-93.5\%), Hirschia (88.8\%), Maricaulis (88.3-88.6\%), Hellea (87.5\%), Oceanicaulis (87.4\%) and Robiginitomaculum ( $86.7 \%$ ), which belong to the family Hyphomonadaceae. All of the $16 \mathrm{~S}$ rRNA gene sequence divergences between strain $\mathrm{P} 38^{\mathrm{T}}$ and recognized species were greater than $6.5 \%$ and the distinct phylogenetic relationships revealed that strain $\mathrm{P} 38^{\mathrm{T}}$ could not be assigned to any of the recognized genera. Consequently, strain $\mathrm{P} 38^{\mathrm{T}}$ should be considered to represent a novel species in a new genus in the family Hyphomonadaceae. In addition, we found that the genus Woodsholea (Abraham

Table 1. Characteristics that differentiate strain $\mathrm{P} 38^{\top}$ from related genera of the family Hyphomonadaceae

Taxa: 1, Maribaculum marinum gen. nov., sp. nov. P38 ${ }^{\mathrm{T}}$; 2, Hyphomonas; 3, Hirschia; 4, Maricaulis; 5, Oceanicaulis; 6, Robiginitomaculum (data in columns 2-6 from Lee et al., 2007); 7, Woodsholea (Abraham et al., 2004); 8, Hellea (Alain et al., 2008). For cellular fatty acid analyses, strains of the genus Hyphomonas were grown on MA. Strains of Hirschia baltica were grown on M13 medium (Schlesner et al., 1990). Strains of the genera Maricaulis and Oceanicaulis were grown on SPYEM medium (Abraham et al., 1999). +, Positive; -, negative; tr, trace; v, variable; ND, no data available.

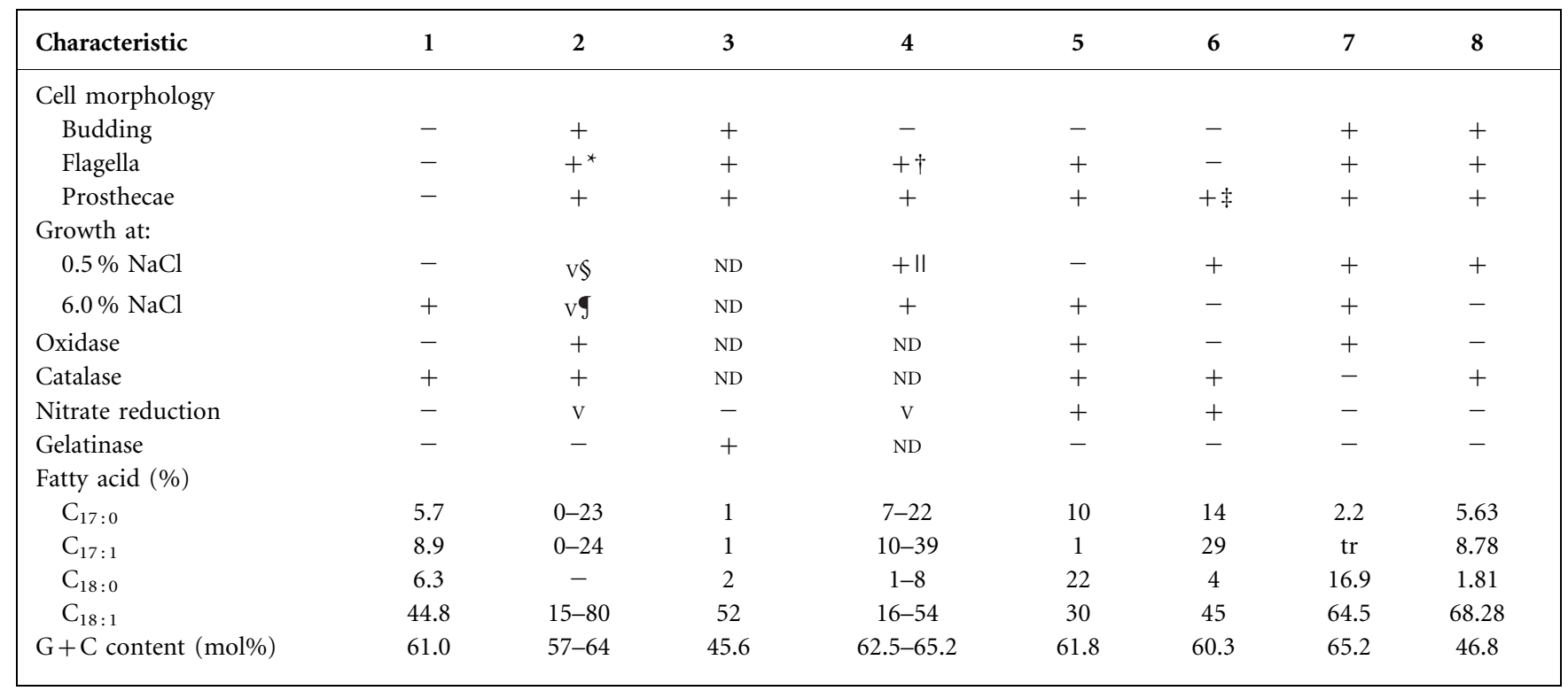

${ }^{*}$ Data for Hyphomonas adhaerens, Hyphomonas johnsonii and Hyphomonas rosenbergii.

$\dagger$ Data for Maricaulis maris.

$¥$ Some cells have a prostheca with a thin, tapered end.

$\$$ All species are negative except Hyphomonas polymorpha.

IIData for all species except Maricaulis maris.

SAll species are positive except Hyphomonas polymorpha. 


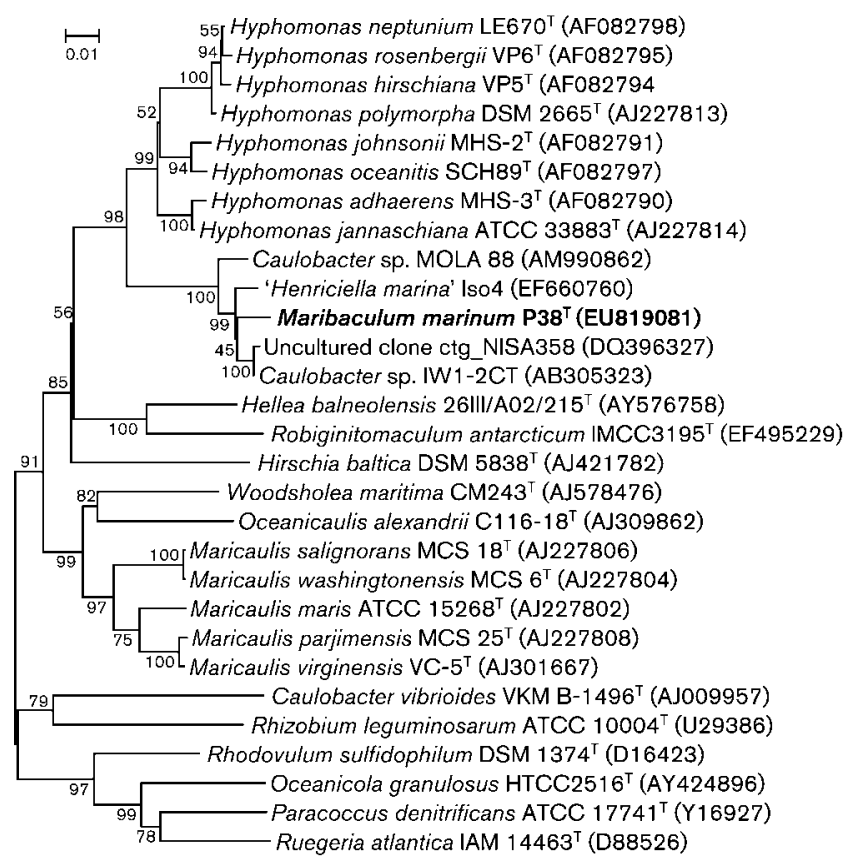

Fig. 1. Neighbour-joining tree showing the phylogenetic positions of strain $\mathrm{P} 38^{\mathrm{T}}$ and other members of the family Hyphomonadaceae, based on 16S rRNA gene sequences. Bootstrap values based on 1000 replications are shown as percentages at branch nodes. Bar, 0.01 nucleotide substitution rate $\left(K_{\text {nuc }}\right)$ units.

et al., 2004) probably belongs to the family Hyphomonadaceae, as shown previously by Alain et al. (2008).

The $\mathrm{G}+\mathrm{C}$ content of the chromosomal DNA was determined according to the methods described by Mesbah \& Whitman (1989) using reversed-phase HPLC. The DNA $\mathrm{G}+\mathrm{C}$ content of strain $\mathrm{P} 38^{\mathrm{T}}$ was $61.0 \mathrm{~mol} \%$, which is similar to values reported for the genera Hyphomonas (57$64 \mathrm{~mol} \%)$, Maricaulis (62.5-65.2 mol\%), Oceanicaulis (61.8 $\mathrm{mol} \%$ ) and Robiginitomaculum (60.3 mol\%), but differs by more than $10 \mathrm{~mol} \%$ from values reported for the genera Hirschia (45.6 mol\%) and Hellea (46.8 mol\%).

Fatty acids from whole cells grown on marine agar 2216 (BD Difco) at $28{ }^{\circ} \mathrm{C}$ for $48 \mathrm{~h}$ were extracted, saponified and esterified. The fatty acid methyl esters were analysed with GC according to the instructions of the MIDI system (Sasser, 1997). The major fatty acids of strain $\mathrm{P} 38^{\mathrm{T}}$ were $\mathrm{C}_{16: 0}(20 \%), \mathrm{C}_{17: 0}(5.7 \%), \mathrm{C}_{18: 1} \omega 7 c \quad(37.7 \%), \mathrm{C}_{18: 0}$ $(6.3 \%)$ and $\mathrm{C}_{18: 1} \omega 7 c 11-$ methyl $(7.1 \%)$. Minor amounts of $\mathrm{C}_{12: 0} 3-\mathrm{OH}(3.7 \%), \mathrm{C}_{14: 0}(0.9 \%), \mathrm{C}_{16: 1} \omega 5 c(4.4 \%)$, $\mathrm{C}_{17: 1} \omega 8 c(4.8 \%), \mathrm{C}_{17: 1} \omega 6 c(4.1 \%), \mathrm{C}_{19: 0}$ cyclo $\omega 8 c$ $(0.9 \%), \mathrm{C}_{18: 1} 2-\mathrm{OH}(2.6 \%)$ and $\mathrm{C}_{20: 0}(1.4 \%)$ were also found in strain $\mathrm{P} 38^{\mathrm{T}}$. These results differentiated strain $\mathrm{P} 38^{\mathrm{T}}$ from members of the genus Hyphomonas, which do not contain $\mathrm{C}_{18: 0}$ (Lee et al., 2007), although it should be noted that Abraham et al. (2004) detected $\mathrm{C}_{18: 0}$ in
Hyphomonas polymorpha DSM $2665^{\mathrm{T}}$ (trace) and Hyphomonas jannaschiana ATCC $33833^{\mathrm{T}}$ (3.7\%).

Although strain $\mathrm{P} 38^{\mathrm{T}}$ is related most closely to members of the genus Hyphomonas (92.3-93.5\% 16S rRNA gene sequence similarity), with the highest similarity to Hyphomonas oceanitis $\mathrm{SCH} 89^{\mathrm{T}}(93.5 \%)$, it cannot be affiliated to the genus Hyphomonas because it is nonbudding and does not produce prosthecae and is nonmotile and oxidase-negative. The low levels of 16S rRNA gene sequence similarity between strain $\mathrm{P} 38^{\mathrm{T}}$ and all of the other members of the family Hyphomonadaceae, together with the differential phenotypic properties shown in Table 1, suggest that strain $\mathrm{P} 38^{\mathrm{T}}$ represents a novel species in a new genus within the family Hyphomonadaceae, for which the name Maribaculum marinum gen. nov., sp. nov. is proposed.

\section{Description of Maribaculum gen. nov.}

Maribaculum (Ma.ri.ba'cu.lum. L. neut. n. mare the sea; L. neut. n. baculum a stick or rod; N.L. neut. n. Maribaculum rod from the sea).

Cells are Gram-negative-staining, short rods or ovoid, nonmotile, non-budding and non-prostheca-producing, oxidase-negative and catalase-positive. Multiplication occurs by binary fission. Flagella and holdfasts are not present. Carotenoid, bacteriochlorophyll $a$ and the genes for anoxygenic photosynthesis ( $p$ ufLM) are not found. Chemoheterotrophic. The dominant fatty acids are $\mathrm{C}_{16: 0}$ and $\mathrm{C}_{18: 1} \omega 7 c$. The DNA G $+\mathrm{C}$ content of the type strain of the type species is $61.0 \mathrm{~mol} \%$. The genus is assigned phylogenetically to the family Hyphomonadaceae in the order Rhodobacterales. The type species is Maribaculum marinum.

\section{Description of Maribaculum marinum sp. nov.}

Maribaculum marinum (ma.ri'num. L. neut. adj. marinum of the sea, marine).

Displays the following properties in addition to those given for the genus. Cells are 1.2-1.4 $\mu \mathrm{m}$ long and $0.8-0.9 \mu \mathrm{m}$ wide. Negative for lipase (Tween 80), amylase, urease, gelatinase, arginine dihydrolase and indole, hydrolysis of aesculin and reduction of nitrate to nitrite. On 216L agar, forms smooth, grey colonies with regular edges that are 2$3 \mathrm{~mm}$ in diameter after $72 \mathrm{~h}$ incubation at $28{ }^{\circ} \mathrm{C}$. Grows with $2-12 \% \mathrm{NaCl}$ (optimum $3-10 \%$ ) and at $10-42{ }^{\circ} \mathrm{C}$ (optimum $25-37^{\circ} \mathrm{C}$ ), but not at 4 or $45^{\circ} \mathrm{C}$ after 7 days. Unable to ferment glucose. The predominant fatty acids are $\mathrm{C}_{16: 0}, \mathrm{C}_{17: 0}, \mathrm{C}_{18: 1} \omega 7 c, \mathrm{C}_{18: 0}$ and $\mathrm{C}_{18: 1} \omega 7 c$ 11-methyl. Sensitive to ( $\mu \mathrm{g}$ per disc unless otherwise stated) cotrimoxazole (25), ofloxacin (5), tetracycline (30), minomycin (30), penicillin G (10), streptomycin (10), ciprofloxacin (5), neomycin (10), vibramycin (30), piperacillin (100), rocephin (30), kanamycin (30), ampicillin (10), gentamicin (10), rifampicin (5), cephradin (30), chloromycetin (30), carbenicillin (100) and erythromycin (15). 
Resistant to cephalexin (30), cephazolin (30), cefobid (30), clindamycin (2), furazolidone (15), lincomycin (2), metronidazole (5), norfloxacin (10), oxacillin (1), polymyxin B (30 U) and vancomycin (30). With API ZYM, positive for acid phosphatase, alkaline phosphatase, cystine aminopeptidase, leucine aminopeptidase, naphthol-AS-BI-phosphoamidase, trypsin, valine aminopeptidase, $\alpha$-chymotrypsin and $\alpha$-glucosidase; weakly positive for esterase (C4), esterase lipase (C8) and lipase (C14); negative for $N$-acetyl- $\beta$-glucosaminidase, $\alpha$-fucosidase, $\alpha$ - and $\beta$-galactosidase, $\alpha$-mannosidase, $\beta$-glucosidase and $\beta$-glucuronidase. With API 20NE, does not utilize adipic acid, capric acid, D-glucose, maltose, D-mannitol, Dmannose, L-arabinose, malic acid, $\mathrm{N}$-acetylglucosamine, phenylacetic acid, potassium gluconate or trisodium citrate. With GN2 MicroPlates, positive for utilization of L-aspartic acid, L-glutamic acid, L-ornithine, L-threonine, Tweens 40 and 80, $\alpha$-ketobutyric acid, $\alpha$-ketoglutaric acid, $\alpha$-ketovaleric acid and $\beta$-hydroxybutyric acid; weakly positive for utilization of acetic acid, cis-aconitic acid, citric acid, D-alanine, D-arabitol, cellobiose, dextrin, Dgalacturonic acid, D-serine, glucuronamide, glycogen, glycyl L-aspartic acid, glycyl L-glutamic acid, lactulose, Lalaninamide, L-alanine, L-alanyl glycine, L-asparagine, Lleucine, L-serine, maltose, pyruvic acid methyl ester, succinic acid monomethyl ester, phenylethylamine, propionic acid, quinic acid, $\alpha$-D-glucose, $\gamma$-aminobutyric acid and $\gamma$-hydroxybutyric acid; negative for utilization of 2,3butanediol, 2-aminoethanol, adonitol, bromosuccinic acid, DL-carnitine, DL-lactic acid, DL- $\alpha$-glycerol phosphate, Dfructose, D-galactonic acid lactone, D-galactose, D-gluconic acid, D-glucosaminic acid, D-glucuronic acid, D-mannitol, D-mannose, melibiose, D-psicose, raffinose, D-saccharic acid, D-sorbitol, trehalose, formic acid, gentiobiose, $\alpha$-Dglucose 1-phosphate, D-glucose 6-phosphate, glycerol, hydroxy-L-proline, i-erythritol, inosine, itaconic acid, Larabinose, L-fucose, L-histidine, L-phenylalanine, L-proline, L-pyroglutamic acid, L-rhamnose, malonic acid, myoinositol, $\mathrm{N}$-acetyl-D-galactosamine, $\mathrm{N}$-acetyl-D-glucosamine, $p$-hydroxyphenylacetic acid, putrescine, sebacic acid, succinamic acid, succinic acid, sucrose, thymidine, turanose, uridine, urocanic acid, xylitol, $\alpha$-cyclodextrin, $\alpha$ lactose, $\alpha$-hydroxybutyric acid and methyl $\beta$-D-glucoside. Table 1 and Supplementary Table S1 show characteristics that can be used to distinguish the type strain from related species.

The type strain, $\mathrm{P} 38^{\mathrm{T}} \quad\left(=\mathrm{CCTCC}\right.$ AB $208227^{\mathrm{T}}=\mathrm{LMG}$ $24711^{\mathrm{T}}=$ MCCC $1 \mathrm{~A} 01086^{\mathrm{T}}$ ), was isolated from deep seawater of the Indian Ocean.

\section{Acknowledgements}

This work was supported financially by the COMRA program (no. DYXM115-02-2-05), the National Infrastructure of Natural Resources for Science and Technology Program of China (no. 2005DKA21209) and the Scientific Research Foundation of Third Insititute of Oceanography, SOA (no. 2009065).

\section{References}

Abraham, W. R., Strömpl, C., Meyer, H., Lindholst, S., Moore, E. R., Christ, R., Vancanneyt, M., Tindall, B. J., Bennasar, A. \& other authors (1999). Phylogeny and polyphasic taxonomy of Caulobacter species. Proposal of Maricaulis gen. nov. with Maricaulis maris (Poindexter) comb. nov. as the type species, and emended description of the genera Brevundimonas and Caulobacter. Int J Syst Bacteriol 49, 1053-1073.

Abraham, W. R., Strömpl, C., Bennasar, A., Vancanneyt, M., Snauwaert, C., Swings, J., Smit, J. \& Moore, E. R. (2002). Phylogeny of Maricaulis Abraham et al. 1999 and proposal of Maricaulis virginensis sp. nov., $M$. parjimensis sp. nov., $M$. washingtonensis sp. nov. and M. salignorans sp. nov. Int J Syst Evol Microbiol 52, 2191-2201.

Abraham, W. R., Strömpl, C., Vancanneyt, M., Bennasar, A., Swings, J., Lunsdorf, H., Smit, J. \& Moore, E. R. B. (2004). Woodsholea maritima gen. nov., sp. nov., a marine bacterium with a low diversity of polar lipids. Int J Syst Evol Microbiol 54, 1227-1234.

Alain, K., Tindall, B. J., Intertaglia, L., Catala, P. \& Lebaron, P. (2008). Hellea balneolensis gen. nov., sp. nov., a prosthecate alphaproteobacterium from the Mediterranean Sea. Int J Syst Evol Microbiol 58, 2511-2519.

Ausubel, F. M., Brent, R., Kingston, R. E., Moore, D. D., Seidman, J. G., Smith, J. A. \& Struhl, K. (editors) (1995). Short Protocols in Molecular Biology: A Compendium of Methods from Current Protocols in Molecular Biology, 3rd edn. New York: Wiley.

Béjà, O., Suzuki, M. T., Heidelberg, J. F., Nelson, W. C., Preston, C. M., Hamada, T., Eisen, J. A., Fraser, C. M. \& DeLong, E. F. (2002). Unsuspected diversity among marine aerobic anoxygenic phototrophs. Nature 415, 630-633.

Dong, X.-Z. \& Cai, M.-Y. (2001). Determinative Manual for Routine Bacteriology. Beijing: Scientific Press (English translation).

Lai, Q., Yuan, J., Wu, C. \& Shao, Z. (2009). Oceanibaculum indicum gen. nov., sp. nov., isolated from deep seawater of the Indian Ocean. Int J Syst Evol Microbiol 59, 1733-1737.

Lee, K.-B., Liu, C.-T., Anzai, Y., Kim, H., Aono, T. \& Oyaizu, H. (2005). The hierarchical system of the 'Alphaproteobacteria': description of Hyphomonadaceae fam. nov., Xanthobacteraceae fam. nov. and Erythrobacteraceae fam. nov. Int J Syst Evol Microbiol 55, 19071919.

Lee, K., Lee, H. K., Choi, T. H. \& Cho, J. C. (2007). Robiginitomaculum antarcticum gen. nov., sp. nov., a member of the family Hyphomonadaceae, from Antarctic seawater. Int $J$ Syst Evol Microbiol 57, 2595-2599.

Liu, C. \& Shao, Z. (2005). Alcanivorax dieselolei sp. nov., a novel alkane-degrading bacterium isolated from sea water and deep-sea sediment. Int J Syst Evol Microbiol 55, 1181-1186.

Mesbah, M. \& Whitman, W. B. (1989). Measurement of deoxyguanosine/thymidine ratios in complex mixtures by high-performance liquid chromatography for determination of the mole percentage guanine + cytosine of DNA. J Chromatogr 479, 297-306.

Moore, R. L., Weiner, R. M. \& Gebers, R. (1984). Genus Hyphomonas Pongratz 1957 nom. rev. emend., Hyphomonas polymorpha Pongratz 1957 nom. rev. emend., and Hyphomonas neptunium (Leifson 1964) comb. nov. emend. (Hyphomicrobium neptunium). Int J Syst Bacteriol 34, 71-73.

Rzhetsky, A. \& Nei, M. (1992). A simple method for estimating and testing minimum-evolution trees. Mol Biol Evol 9, 945-967.

Rzhetsky, A. \& Nei, M. (1993). Theoretical foundation of the minimum-evolution method of phylogenetic inference. Mol Biol Evol 10, 1073-1095. 
Saitou, N. \& Nei, M. (1987). The neighbor-joining method: a new method for reconstructing phylogenetic trees. Mol Biol Evol 4, 406-425.

Sambrook, J., Fritsch, E. F. \& Maniatis, T. (1989). Molecular Cloning: a Laboratory Manual, 2nd edn. Cold Spring Harbor, NY: Cold Spring Harbor Laboratory.

Sasser, M. (1997). Identification of bacteria by gas chromatography of cellular fatty acids. MIDI Technical Note 101. Newark, DE: MIDI Inc.

Schlesner, H., Bartels, C., Sittig, M., Dorsch, M. \& Stackebrandt, E. (1990). Taxonomic and phylogenetic studies on a new taxon of budding, hyphal Proteobacteria, Hirschia baltica gen. nov., sp. nov. Int J Syst Bacteriol 40, 443-451.
Shieh, W. Y., Chen, Y.-W., Chaw, S.-M. \& Chiu, H.-H. (2003). Vibrio ruber sp. nov., a red, facultatively anaerobic, marine bacterium isolated from sea water. Int J Syst Evol Microbiol 53, 479-484.

Strömpl, C., Hold, G. L., Lünsdorf, H., Graham, J., Gallacher, S., Abraham, W. R., Moore, E. R. \& Timmis, K. N. (2003). Oceanicaulis alexandrii gen. nov., sp. nov., a novel stalked bacterium isolated from a culture of the dinoflagellate Alexandrium tamarense (Lebour) Balech. Int J Syst Evol Microbiol 53, 1901-1906.

Tamura, K., Dudley, J., Nei, M. \& Kumar, S. (2007). MEGA4: molecular evolutionary genetics analysis (MEGA) software version 4.0. Mol Biol Evol 24, 1596-1599. 